\title{
Bt insecticidal efficacy variation and agronomic regulation in Bt cotton
}

\author{
LIU Zhenyu', ELTAYIB H M. A. Abidallha ${ }^{1,2}$, WU Huimin ${ }^{1}$, ZHOU Mingyuan', ZHANG Xiang ${ }^{1}$, CHEN Yuan ${ }^{1}$ and \\ CHEN Dehua ${ }^{1 *}$ (D)
}

\begin{abstract}
The bollworm can be controlled effectively with Bacillus thuringiensis transgenic cotton (Bt cotton) which is being applied worldwide. However, the insecticidal efficacy is not stable. Here we give a summary of research progress for the mechanism of the altered insecticidal efficacy, factors affecting the expression of insect resistance, agronomic practices on regulation of insecticidal efficacy in Bt cotton. To realize the transgenic potential of Bt cotton cultivars, future research may be conducted by increasing synthesis and reducing degradation of Bt protein to maintain high insecticidal ability in the transgenic cotton by agronomic management.
\end{abstract}

Keywords: Bt cotton, Insecticidal efficacy, Mechanism, Agronomic regulation

Transgenic cottons producing the Bt insecticidal proteins of Bacillus thuringiensis were first commercially planted in Australia, Mexico, and USA in 1996, followed by China (1997), Argentina (1998), South Africa (1998), Colombia (2002), India (2002), Brazil (2005) and Burkina Faso (2008), and have occupied $80 \%$ of the total global cotton area (International Service for the Acquisition of Agri-biotech Applications (ISAAA), 2018). The three largest cotton producers in the world, China, India, and USA, have very high adoption rates $(86 \%-95 \%$ in 2017) contributing to about $80 \%$ of the global Bt cotton area (ISAAA, 2018). In 2017, more than 2.78 million hectares of transgenic Bt cotton, $86.1 \%$ of the total cottongrowing area, were cultivated in China (ISAAA, 2018). However, unstable insect resistance of Bt cotton during cotton growth season is observed, and more studies focused on the expression of Bt protein and regulation. Therefore, a summary of research progress for the altered insecticidal efficacy, factors affecting the expression of insect resistance and related mechanism is useful for stable increment of insecticidal efficacy in Bt cotton.

\section{Insecticidal efficacy for Bt cotton}

The bollworm could be controlled in Bt transgenic cotton effectively

The impact of Bt cotton on larvae of Helicoverpa amigera (Hübner) and the damage to the bollworm is enormous (Chen et al. 2017a). The tansgenic Bacillus thuringiensis cotton, encoding the Cry1Ac, Cry2Ab, or Cry1F protein, could guard againist the harm of bollworm effectively (Shen et al. 2010; Steven et al. 2016). Sanahuja et al. (2011) reported the efficacy of Bt cotton on the control of pink bollworm. Bt cottons producing Cry1Ac or Cry1Ac plus Cry2Ab proteins have been proved to be efficient against pink bollworm, which provide almost $100 \%$ insect resistance compared with the control (Tabashnik et al. 2012). The effects were also detected in other crops (Deng et al. 2019; Andrea et al. 2018). The application of Bt cotton in northern China resulted in the greater repression of Helicoverpa armigera in cotton (Qiao et al. 2017), and at the same time the quantity of the pest in other crops decreased including maize, peanuts, soybeans, etc. However, Lu et al. (2010) reported that suppression of certain pests by Bt cotton cultivation in China may lead to increasing harm by bugs at present. The insecticidal mechanism of the Cry toxin was further revealed that solubilization of the crystal in the insect midgut, decomposition of the protein, binding of the toxin to the midgut receptors, and damage of the apical membrane resulted in death of the

\footnotetext{
${ }^{1}$ Jiangsu Provincial Key Laboratory of Crops Genetics and Physiology,

Yangzhou University, Yangzhou 225009, China

Full list of author information is available at the end of the article
} 
insect (Kranthi et al. 2005; Lu et al. 2013; Juan and Neil 2017).

\section{Insecticidal efficacy varied with growth period and different organs during cotton growth season for $\mathrm{Bt}$ cotton}

In order to maintain the insect resistance of Bt cotton, it is of significance that the Bt protein should be produced in adequate amount in susceptible plant organs at scheduled growth period to prevent the harm of target pests. However, a lot of studies have suggested the fluctuation expression of Bt protein content during the cotton growing season, leading to varied insecticidal efficacy (Wan et al. 2005; Chen et al. 2017b; Alejandra et al. 2019). Significant reduction of insect resistance for Helicoverpa spp. was observed during the growing season, especially after flowering (Wu 2007; Kristen et al. 2013; Chen et al. 2017b). The leaves toxin carrying Cry1Ac were significantly decreased as the crop approached maturation (Wu et al. 2003; Chen et al. 2004), while the toxin level, carrying both Cry1Ac and Cry1Ab genes, was higher during the early growth stages and dropped significantly from anthesis onwards in cotton. The differences of $\mathrm{Bt}$ protein concentrations among studied cultivars can change up to double during the whole growing season (Adamczyk et al. 2001; Adamczyk and Hubbard 2006). The Bt cotton resistance maintained only for 110 days, after which the toxin level dropped below the lethal level of $1.9 \mu \mathrm{g} \bullet \mathrm{g}^{-1}$, and thus the cotton may be harmed by the bollworm again (Guo et al. 2001; Kranthi et al. 2005). It is widely noted that the high insecticidal ability appeared at seedling and squaring period, but dropped markedly during boll formation period for most applied cultivars in Bt cotton (Xia et al. 2005; Chen et al. 2012b, 2017b). Besides the temporal variation of insecticidal efficacy, Bt protein contents also have big difference at different parts and organs of the cotton plants. The concentration of Bt protein was significantly higher in leaves than that in other vegetative organs during the seedling period, including roots, stems and petioles, and ovaries expressed significantly more Bt toxin than pistils and stamens at the anthesis. The highest Cry1Ac expression was noted in leaves, followed by squares, bolls and flowers (Kranthi et al. 2005; Chen et al. 2017b, 2018). The ovary of flowers and rinds of green bolls, the most favored parts that bollworm attacked, exhibited the lowest toxin expression (Kranthi et al. 2005). In addition, variation of $\mathrm{Bt}$ protein expression was also observed between leaves of different ages, for a seven to nine leafstage plant, the fully expanded leaves on main stem exhibited much higher Bt protein content than older basal leaves, while the young leaves on the top part had the lowest level (Chen et al. 2000). The variation of Bt toxin concentration in growth period (temporal) and different parts/organs (spatial) might enhance the pests surviving probability, which has been paid the close attention by cotton farmers and related researchers (Gutierrez et al. 2006; Chen et al. 2018; Chen et al. 2019).

\section{Increased resistance of target pest in Bt cotton}

Along with the Bt protein expression, other challenges such as evolvement of insect resistance to the toxin still limit the efficacy of Bt cotton, which would result in failure of this control method (Sharon et al. 2016). The bollworm ( $H$. armigera) as a main target pest by Bt cotton has demonstrated to evolve resistance to the $\mathrm{Bt}$ toxin according to laboratory selection experiments across the world (Xu et al. 2005; Huang et al. 2017; Vinod et al. 2018). As the results of continuous and widespread cultivation of $\mathrm{Bt}$ cotton, the pest might increase resistance and counteract the insecticidal effect (Alejandra and Mario 2008; Herrero et al. 2016). Although no field insect populations have been reported to increase resistance to $\mathrm{Bt}$ cotton, studies have shown that some insect species could enhance resistance to certain Bt proteins (Tabashnik et al. 2003; Caroline and Juan 2019).

\section{Factors affecting expression of insect resistance in Bt cotton}

Effects of environmental stress on insecticidal efficacy in Bt cotton

Environmental stresses, such as extreme temperature, water deficit, salinity stress, or light stress, would reduce both the yield and quality of many crops. Previous researches confirmed that Bt protein expression was also affected by environmental stress. High temperature $\left(37^{\circ} \mathrm{C}\right)$ significantly decreased the Bt toxin concentration at bolling period (Chen et al. 2005). Treatment with 200 $\mathrm{mm} \mathrm{NaCl}$ exhibited significant reduction of Bt protein content in the functional leaves in Bt cotton (Jiang et al. 2006). Either water logging or drought significantly decreased the Bt toxin expression (Luo et al. 2008; Zhang et al. 2017), but the extent of reduction varied with plant organs and positions. Significant reduction of Bt protein was detected in older leaves by water deficient, but greater decrease was caused for squares by water logging (Chen et al. 2012a). Variance of insect resistance for low sensitive insect species such as cotton bollworm and armyworm was related to the difference of Cry1Ac expression in the field, which was impacted by variety background, field site (environment) and plant age (Chen et al. 2012b, 2017b, 2018). Chen et al. (2012b) reported that air relative humidity and temperature in the cotton field impacted leaf endotoxin level, and high temperature $\left(37^{\circ} \mathrm{C}\right)$ also resulted in remarkable reduction of the cotton square Bt protein (Wang et al. 2015). Therefore, factors such as rainfall, the severity of pests 
and diseases, soil characteristics, and timely, appropriate and adequate farming management have direct or indirect impacts on the insecticidal ability. All the factors together with the inherent factors in the cultivars contribute to the different performances of transgenic $\mathrm{Bt}$ cotton. Providing an optimal environment for Bt cotton production may be necessary for strengthening the potential of Bt gene expression.

However, not all environmental stresses reduced the Bt protein expression. Under mild adverse environmental conditions, when $\mathrm{NaCl}$ concentration did not exceed $100 \mathrm{mmol} \bullet \mathrm{L}^{-1}$, no significant difference was observed between the stress treated plants and untreated control (Jiang et al. 2006). Wherever an environmental stress happened, the plants response was induced and changed their metabolic level, which might be able to keep the critical toxin level (Mahon et al. 2002). Moreover, under some circumstances, the Bt protein content was markedly decreased (Chen et al. 2012a; Chen et al. 2019), but the $\mathrm{Bt}$ protein level did not drop below the threshold level, which was still high enough to against pests. Kranthi et al. (2005) thought the threshold value as 1.9 $\mathrm{ng} \bullet \mathrm{g}^{-1}$, and toxin level would fall below the critical level only after 110 days after planting. In spite of the variation in Bt protein concentration according to previous researches, the insecticidal ability still lasted until 100115 days after sowing.

\section{Agronomic practices on insecticidal efficacy in Bt cotton}

There are some reports on the improvement of Cry1Ac protein expression in $\mathrm{Bt}$ cotton through agronomic practices like high doses of $\mathrm{N}$ fertilizer (Pettigrew and Adamczyk 2006). Chen et al. (2019) reported that the fertilizer application rates influenced the Bt toxin expression, and the efficacy of Bt cotton reduced markedly if nitrogen rates were low during cotton growth. The recovery was further proved that nitrogen fertilizer enhanced $\mathrm{Bt}$ protein expression and insect resistance (Oosterhuis and Brown 2004; Wang et al. 2012; Chen et al. 2018). N deficit resulted in reduced Bt protein concentration (Chen et al. 2004; Zhang et al. 2017). High $\mathrm{N}$ fertilizer rates enhanced the leaf Bt protein content by $14 \%$ compared with light nitrogen rates. Nitrogen metabolic physiology had close relationships with Bt protein concentration in Bt cotton (Chen et al. 2005; Chen et al. 2013; Chen et al. 2019). Nitrogen metabolic strength influenced the Bt protein concentration of cotton organs (Chen et al. 2004; Chen et al. 2017a, 2017b), and nitrogen deficit reduced the content of Bt protein in Bt cotton (Chen et al. 2018; Chen et al. 2019). The concentration of Bt protein in plant tissues was significantly correlated with the content of total soluble protein and total nitrogen (Oosterhuis and Brown 2004; Dong et al. 2007; Wang et al. 2012; Chen et al. 2018). Abidallha et al. (2017) reported that the leaf Bt toxin was enhanced markedly by the external uses of Aspartic acid, Glutamic acid, Glycine, Proline, Tyrosine, Methionine, Phenylalanine, Histidine and Arginin at boll period, however, at square period, leaf Bt toxin was only significantly increased by Aspartic acid, Glutamic acid, Proline, Methionine, Arginin and the extent of increase was relatively low. The research of Huang et al. (2010) showed that application of phosphate and potash fertilizers, and manure, has significant positive effects on $\mathrm{Bt}$ toxin expression in fields, and the toxin content is positively related with the application of phosphate fertilizer, potash fertilizer and manure.

Plant density also could influence the square insect resistance. Higher square number per plant and square volume together with enhanced square Bt toxin concentration were detected under lower planting density, whereas contrary effects were noted under high planting density (Chen et al. 2017a, 2017b).

Plant growth regulator (PGR) also could affect the insect resistance of Bt toxin centration (Ian 2006; Feng et al. 2007). The late-season Bt toxin content, particularly in squares, was greatly elevated by foliar applications of chaperone, a plant growth regulator (Oosterhuis and Brown 2004). The square Bt toxin concentration was enhanced by $\mathrm{GA}_{3}$ application, resulting in lower bollworm number and hazard rate with higher yield (Chen et al. 2017a, 2017b). DPC and GA3 application increased boll Bt toxin concentration. However, at early boll formation stages, $\mathrm{GA}_{3}$ decreased the boll Bt toxin level (Chen et al. 2017a, 2017b). Other farm managements, such as early sowing (in April) also decreased leaf Bt toxin concentration by $12 \%$ relative to the late planting (Pettigrew and Adamczyk 2006).

\section{The insect resistant variation in Bt cotton relate to Cry1 Ac transcript and physiology of carbon and nitrogen metabolism}

The Bt protein expression could be affected by the nucleotide sequence, the promoter, the insertion point of the gene in the DNA of the Bt cotton cultivars, the trans-gene amplification, the environment factors in the cell and natural condition (Hobbs et al. 1993; Rao 2005; Sharon et al. 2016; Wang et al. 2018). Thus, in order to understand the differential expression of transgenes, the study at molecular, genetic, as well as physiological levels should be important.

The Bt protein contents reduced significantly after squaring period, and the reduction was attributed to the altered mRNA production (Mahon et al. 2002). Bt toxin contents reduced consistent with the growing period, and the reduction was associated with the decrease of mRNA production (Chen et al. 2017a, 2017b; Sharon et al. 2016). Olsen et al. (2005) found that the reduction 
with growth stage in efficacy against target pests was a result of decreased Cry1Ac transcript levels and thus Bt protein levels after squaring in the field.

Variations of insect resistance were concluded as a result of altered gene expression as the crop maturation. Xia et al. (2005) found that the Bt toxin gene expression exhibited a temporal and spatial variation, and toxin concentration reduced as the crop mature due to the reduction in full-length Bt toxin gene transcripts. The over expression of $\mathrm{Bt}$ gene at earlier stages of transgenic cotton plants resulted in gene regulation at the posttranscription level and caused the gene silencing consequently. And the post-transcription regulation was through the alteration in the methylation state of the $35 \mathrm{~S}$ promoter region of Bt gene at later growth stages.

Bt toxin levels were reported to be closely related with the carbon and nitrogen metabolism according to a number of researches. The relative availability of carbon and nitrogen nutrients as along with their relationship with the plant growth rates all contributed to the allocation pattern of defensive compounds (Bryant et al. 1983; Chen et al. 2017b). The enhance of carbon-based defense was attributed to elevated photosynthesis or reduced nitrogen supply, in contrast, the enhanced nitrogen-based defense was caused by opposite situation (Faje et al. 1989; Chen et al. 2019). The Bt protein concentration was influenced by an interaction between nitrogen and $\mathrm{CO}_{2}$, and reduced $\mathrm{N}$ allocation to Bt protein was observed under enhanced $\mathrm{CO}_{2}$ (Coviella et al. 2002). Enhanced protein level was observed under increased available $\mathrm{N}$, especially in vegetative cells (Chen et al. 2017b). According to the fact that most increased proteins are enzymes, when available nitrogen elevates, it is highly possible that more Bt protein synthesizing enzymes and/or mRNA would be produced, thus more Bt toxins would be produced (Bruns and Abel 2003; Chen et al. 2018). Adamczyk and Meredith (2004) found that the leaf tissue with low chlorophyll content had low Bt toxin concentration, and indicated that photosynthesis-regulating factors associated with mRNA transcription and translation should affect the insecticidal protein expression. Furthermore, Olsen and Daly (2000) reported that not only lower toxin protein content was observed in older plants, but also the toxin is either less toxic or less available. The protein decomposition and remobilization of nitrogen also led to Bt toxin content reduction. Exposure of Bt transgenic cotton plants to high temperature resulted in a significant decline in glutamic-pyruvic transaminase (GPT) activity and soluble protein content, suggesting that high temperature may result in the degradation of soluble protein in the leaf, with a resulting decline in the level of the toxin Cry1A (Chen et al. 2005), the conclusion was proved by other reports (Chen et al. 2012b; Zhang et al.
2017; Chen et al. 2019). Pettigrew and Adamczyk (2006) reported that relocation of leaf nitrogen to boll in earlyplanted cotton resulted in decreased level of Bt protein relative to late-planted cotton plants. Furthermore, when non-Bt cotton plants were grafted to Bt plants, Bt toxin protein could be detected in leaves of non-Bt cotton and xylem sap of Bt cotton, indicating the transportable property of Bt toxin (Rui et al. 2005). In sum, previous researches indicated that reduced Bt toxin level might be associated with nitrogen metabolism in Bt cotton, including remobilization, inhibited synthesis, and/or elevated degradation (Chen et al. 2017a, 2017b; Chen et al. 2019).

\section{Research prospects}

All previous researches suggested that the growth and physiological status of the Bt cotton organs affected the insecticidal protein concentration. Although it is still not perfect, Bt cotton has been proven as one of the most effective and environment-friendly approaches of insect control so far (Kranthi et al. 2005). However, little is known what happen to the vegetative and reproductive growth after Bt gene introduction, and in turn how the square and boll development influence the insecticidal protein expression. Previous studies had also found that the nitrogen metabolism had close relationship with insecticidal concentration in Bt cotton (Chen et al. 2012a, 2012b, 2017a, 2017b). Therefore, studying the relationships of the nitrogen metabolism with both the square and boll development and insecticidal protein concentration is important to illustrate the mechanism of the effect of square and boll development on insect resistance. Furthermore, finding a way to bolster Bt protein content during yield formation period is also important for Bt cotton production.

Besides providing new cotton varieties with more powerful resistance to insect pests, according to the fact that insecticidal efficacy was related to nitrogen metabolism, future researches may be conducted to increase synthesis and reduce degradation of Bt protein for maintaining high insecticidal ability in the transgenic cotton which carry out by agronomic management in realizing the insecticidal potential for Bt cotton cultivars.

\section{Acknowledgments}

Not applicable.

Authors' contributions

LZY finished the draft writing; EMAA, WHM, ZMY, ZX and CY collected the data for related paper; $\mathrm{CDH}$ was a major contributor in writing the manuscript. All authors read and approved the final manuscript.

\section{Funding}

The work was supported by National Natural Science Foundation of China (\#31671613), by the National Key R\&D Program of China(\#2018YFD0100406, \#2017YFD0201306), by Priority Academic Program Development of Jiangsu 
Higher Education Institutions, China (PAPD), and by the Brand Professional Construction Program of Jiangsu Higher Education Institutions, China.

\section{Availability of data and materials}

Not applicable.

\section{Ethics approval and consent to participate}

Not applicable

\section{Consent for publication}

The work has not been published elsewhere, and all authors agree to submit in Journal of Cotton Reseach.

\section{Competing interests}

The authors declare that they have no competing interests.

\section{Author details}

'Jiangsu Provincial Key Laboratory of Crops Genetics and Physiology, Yangzhou University, Yangzhou 225009, China. ${ }^{2}$ Department of Forest Management, Faculty of Forestry, University of Khartoum, 13314 Khartoum, Sudan.

Received: 12 September 2019 Accepted: 25 November 2019

Published online: 23 December 2019

\section{References}

Abidallha HAE, Li Y, Hen L, et al. Amino acid composition and level affect Bt protein concentration in Bt cotton. Plant Growth Regul. 2017;82(3):439-46. https://doi.org/10.1007/s10725-017-0270-7.

Adamczyk JJ, Adams LC HDD, Sumerford DV. Correlating differences in larval survival and development of bollworm (Lepidopera: Noctuidae) and fall armyworm (Lepidoptera: Noctuidae) to differential expression of Cry 1 Ac deltaendotoxin in various plant parts among commercial cultivars of transgenic Bacillus thuringiensis cotton. J Econ Entomol. 2001;94:284-90.

Adamczyk JJ, Hubbard D. Changes in populations of Heliothis virescens (F.) (Lepidoptera: Noctuidae) and Helicoverpa zea (Boddie) (Lepidoptera: Noctuidae) in the Mississippi Delta from 1986 to 2005 as indicated by adult male pheromone traps. J Cotton Sci. 2006;10:155-60.

Adamczyk JJ, Meredith WR. Genetic basis for the variability of CrylAc expression among commercial transgenic Bacillus thuringiensis (Bt) cotton cultivars in the United States. J Cotton Sci. 2004;8:17-23.

Alejandra B, Mario S. How to cope with insect resistance to Bt toxins? Trends Biotechnol. 2008;26:573-9.

Alejandra B, Sarjeet SG, Mario S. Bacillus thuringiensis: mechanisms and use. In: Schmidt T, editor. Encyclopedia of Microbiology. $4^{\text {th }}$ ed. Salt Lake City, USA: Academic Press; 2019. p. 307-32

Andrea KC, Siddique IA, Leah LS, et al. Risks and opportunities of GM crops: Bt maize example. Glob Food Secur. 2018:19:84-91.

Bruns HA, Abel CA. Nitrogen fertility effects on Bt-endotoxin and nitrogen concentrations of maize during early growth. Agron J. 2003;95:207-11.

Bryant JP, Chapin FS, Klein DR, 1983. Carbon nutrient balance of boreal plants in relation to vertebrate herbivory. Qikos, 40, 357-368.

Caroline PDB, Juan LF. Mechanisms of resistance to commercially relevant entomopathogenic bacteria. Curr Opin Insect Sci. 2019;33:56-62.

Chen DH, Ye GY, Yang CQ, et al. Effect after introducing Bacillus thuringiensis gene on nitrogen metabolism in cotton. Field Crops Res. 2004;87:235-44.

Chen DH, Ye GY, Yang CQ, et al. The effect of high temperature on the insecticidal properties of Bt cotton. Environ Exp Bot. 2005;53:333-40.

Chen S, Wu J, Zhou B, et al. On the temporal and spatial expression of Bt toxin protein in Bt transgenic cotton. Acta Gossypii Sin. 2000;12:189-93 (in Chinese with English abstract).

Chen WB, Lu GQ, Cheng HM, et al. Transgenic cotton coexpressing Vip3A and Cry 1 Ac has a broad insecticidalspectrum against lepidopteran pests. J Invertebr Pathol. 2017a;149:59-65.

Chen $Y$, Chen $Y$, Wen YJ, et al. The effects of the relative humidity on the insecticidal expression level of Bt cotton during bolling period under high temperature. Field Crop Res. 2012b;137:141-7.

Chen Y, Li Y, Chen Y, et al. Planting density and leaf-square regulation affected square size and number contributing to altered insecticidal protein content in Bt cotton. Field Crops Res. 2017b;205:14-22. https://doi.org/10.1016/j.fcr. 2017.02.004
Chen Y, Li Y, Zhou MY, et al. Nitrogen deficit decreases seed Cry1Ac endotoxin expression in Bt transgenic cotton. Plant Physiol Biochem. 2019:141:114-21.

Chen Y, Li Y, Zhou MY, et al. Nitrogen (n) application gradually enhances boll development and decreases boll shell insecticidal protein content in $\mathrm{n}$ deficient cotton. Front Plant Sci. 2018:9:51. https://doi.org/10.3389/fpls.2018. 00051.

Chen $Y$, Wen $Y$, Chen $Y$, et al. Effects of extreme air temperature and humidity on the insecticidal expression level of Bt cotton. J Integr Agric. 2012a;11:101-8.

Chen Y, Wen Y, Chen Y, et al. The recovery of Bt toxin content after temperature stress termination in transgenic cotton. Span J Agric Res. 2013;11(2):438-46.

Coviella CE, Stipanovic RD, Trumble JT. Plant allocation to defensive compounds: interactions between elevated $\mathrm{CO}_{2}$ and nitrogen in transgenic cotton plants. J Exp Bot. 2002;53:323-31.

Deng JX, Wang YM, Yang FY, et al. Persistence of insecticidal cry toxins in Bt rice residues under field conditions estimated by biological and immunological assays. Sci Total Environ. 2019;679:45-51.

Dong HZ, Li WJ, Tang W, et al. Heterosis in yield, endotoxin expression and some physiological parameters in Bt transgenic cotton. Plant Breed. 2007;126:16975.

Faje ED, Bowers MD, Bazzaz FAT. The effects of enriched carbon dioxide atmospheres on plant-insect herbivore interactions. Science. 1989;243:1198-200.

Feng YJ, Wang JW, Luo SM. Effects of exogenous Jasmonic acid on concentrations of direct-defense chemicals and expression of related genes in Bt (Bacillus thuringiensis) corn (Zea mays). Agric Sci China. 2007;6:1456-62.

Guo WZ, Sun J, Guo YF, Zhang TZ. Investigation of different dosage of inserted Bt genes and their insect-resistance in transgenic Bt cotton. Acta Genet Sin. 2001;28:668-76.

Gutierrez AP, Adamczyk JJ, Ponsard S, Ellis CK. Physiologically based demographics of Bt cotton-pest interactions II. Temporal refuges, natural enemy interactions. Eco Model. 2006;191:360-82.

Hobbs SL, Warkentin AD, Delong CO. Transgene copy number can be positively or negatively associated with transgene expression. Plant Mol Biol. 1993;21: $17-26$.

Huang JK, Mi JW, Lin H, et al. A decade of Bt cotton in Chinese field: assessing direct effect and indirect externalities of Bt cotton adoption in China. Sci China Life Sci. 2010;53(8):981-91.

Huang YX, Qin Y, Feng HQ, et al. Modeling the evolution of insect resistance to one- and two-toxin Bt-crops in spatially heterogeneous environments. Ecol Model. 2017;347:72-84

Ian JR. Effect of genotype, edaphic, environmental conditions, andagronomic practices on Cry1Ac protein expression in transgenic cotton. J Cotton Sci. 2006;10:252-62.

International Service for the Acquisition of Agri-biotech Applications. Global status of commercialized biotech/GM crops in 2017. China Biotechnol. 2018; 38(6):1-8.

Jiang $L$, Duan $L$, Tian $X L$, et al. NaCl salinity stress decreased Bacillus thuringiensis (Bt) protein content of transgenic Bt cotton (Gossypium hirsutum L.) seedlings. Environ Exp Bot. 2006;55:315-20.

Juan LF, Neil C. Specificity determinants for Cry insecticidal proteins: insights from their mode of action. J Invertebr Pathol. 2017;142:5-10.

Kranthi KR, Naidu S, Dhawad CS, et al. Temporal and intraplant variability of Cry 1 Ac expression in Bt-cotton and its influence on the survival of the cotton bollworm, Helicoverpa armigera. Curr Sci. 2005:89:291-8.

Kristen K, Graham H, John R. Season-long expression of Cry1Ac and Cry2Ab proteins in Bollgard II cotton in Australia. Crop Prot. 2013:44:50-8.

Lu Q, Cao GC, Zhang LL, et al. The binding characterization of Cry insecticidal proteins to the brush border membrane vesicles of Helicoverpa armigera, Spodoptera exigua, Spodoptera litura and Agrotis ipsilon. J Integr Agric. 2013; 12:1598-605.

Lu YH, Wu KM, Jiang YY, et al. Mirid bug outbreak in multiple crops correlated with wide scale adoption of Bt cotton in China. Science. 2010;328:1151-4.

Luo Z, Dong HZ, Li WJ, et al. Individual and combined effects of salinity and waterlogging on Cry1 Ac expression and insecticidal efficacy of Bt cotton. Crop Prot. 2008:27:1485-90.

Mahon R, Finnergan J, Olsen K, Lawrence L. Environmental stress and the efficacy of Bt cotton. Aust Cotton Grower. 2002;22:18-21.

Olsen KM, Daly JC. Plant-toxin interactions in transgenic Bt cotton and their effect on mortality of Helicoverpa armigera (Lepidoptera: Noctuidae). J Econ Entomol. 2000;4:1293-9.

Olsen KM, Daly JC, Holt HE, Finnegan EJ. Season-long variation in expression of Cry1Ac gene and efficacy of Bacillus thuringiensis toxin in transgenic cotton 
against Helicoverpa armigera (Lepidoptera: Noctuidae). J Econ Entomol. 2005; 98:1007-17.

Oosterhuis DM, Brown RS. Effect of foliar Chaperone ${ }^{\mathrm{TM}}$ applications on endotoxin and protein concentration, insect mortality and yield response of cotton. Ark Agri Exp Sta Res Ser. 2004;533:51-6.

Pettigrew WT, Adamczyk JJ. Nitrogen fertility and planting date effects on lint yield and Cry1ac (Bt) endotoxin production. Agron J. 2006;98:691-7. https:// doi.org/10.2134/agronj2005.0327 .

Qiao FB, Huang JK, Wang XB. Fifteen years of Bt cotton in China: results from household surveys. World Dev. 2017;98:351-9. https://doi.org/10.1016/j. worlddev.2017.05.006.

Rao CK. Transgenic Bt technology: 3. Expression of transgenes. 2005. http:/www. monsanto.co.uk/news/ukshowlib.phtml?uid?9304.

Rui Y, Zhu B, Luo Y. Long distance transportation of Bt-toxin through xylem sap in Bt cotton (Gossyposium). Chinese Bull Bot. 2005;22:320-4.

Herrero S, Bel Y, Hernández-Martínez P, Ferré J. Susceptibility, mechanisms of response and resistance to Bacillus thuringiensis toxins in Spodoptera spp. Curr Opin Insect Sci. 2016;15:89-96. https://doi.org/10.1016/j.cois.2016.04.006.

Sanahuja G, Banakar R, Twyman RM, et al. Bacillus thuringiensis: a century of research, development and commercial applications. Plant Biotechnol J. 2011;9:283-300.

Sharon D, Tom W, Wee T. Bt resistance in Australian insect pest species. Curr Opin Insect Sci. 2016;15:78-83.

Shen P, Lin KJ, Zhang YJ, et al. Seasonal expression of Bacillius thuringiensis insecticidal protein and control to cotton bollworm indifferent varieties of transgenic cotton. Cotton Sci. 2010;22:393-7 (in Chinese with English abstract).

Steven LL, Geoffrey MM, Joshua PU. Assessing the potential for interaction between the insecticidal activity of two genetically engineered cotton events combined by conventional breeding: an example with COT102MON 15985. Regul Toxicol Pharmacol. 2016;79:35-41.

Tabashnik BE, Carrière Y, Dennehy TJ. Insect resistance to transgenic Bt crops: lessons from the laboratory and field. J Econ Entomol. 2003;96:1031-8.

Tabashnik BE, Wu KM, Wu YD. Early detection of field-evolved resistance to Bt cotton in China: cotton bollworm and pink bollworm. J Invertebr Pathol. 2012;1 10:301-6. https://doi.org/10.1016/j.jp.2012.04.008.

Vinod SK, Singh TK, Keshav RK, David AA. Cry1Ac resistance allele frequency in field populations of Helicoverpa armigera (Hübner) collected in Telangana and Andhra Pradesh, India. Crop Protection. 2018;107:34-40.

Wan P, Zhang Y, Wu K, Huang M. Seasonal expression profiles of insecticidal protein and control efficacy against Helicoverpa armigera for Bt cotton in the Yangtze River valley of China. J Econ Entomol. 2005;98:195-201.

Wang F, Jian Z, Nie L, et al. Effects of N treatments on the yield advantage of BtSY63 over SY63 (Oryza sativa) and the concentration of Bt protein. Field Crop Res. 2012;129:39-45.

Wang J, Chen Y, Yao M, et al. The effects of high temperature level on square bt protein concentration of Bt cotton. J Integr Agric. 2015;14:1971-9. https:// doi.org/10.1016/S2095-3119(15)61049-8.

Wang SH, Wendy K, Wang P. Bacillus thuringiensis Cry1A toxins exert toxicity by multiple pathways in insects. Insect Biochem Mol Biol. 2018;102:59-66.

Wu KM. Monitoring and management strategy for Helicoverpa armigera resistance to Bt cotton in China. J Invertebr Pathol. 2007;95:220-3.

Wu KM, Guo Y, Greenplate JT, Deaton R. Efficacy of transgenic cotton containing Cry1Ac gene from Bacillus thuringiensis against Helicoverpa armigera in northern China. J Econ Entomol. 2003;96:1322-8.

Xia L, Xu Q, Guo S. Bt insecticidal gene and its temporal expression in transgenic cotton plants. Acta Agron Sin. 2005;31:197-202.

Xu X, Yu L, Wu Y. Disruption of a cadherin gene associated with resistance to Cry1Ac $\delta$-endotoxin of Bacillus thuringiensis in Helicoverpa armigera. Appl Environ Microbiol. 2005;71:948-54.

Zhang $X$, Wang J, Peng S, et al. Effects of soil water deficit on insecticidal protein expression in boll shells of transgenic Bt cotton and the mechanism. Front Plant Sci. 2017;8:2107. https://doi.org/10.3389/fpls.2017.02107.

Ready to submit your research? Choose BMC and benefit from:

- fast, convenient online submission

- thorough peer review by experienced researchers in your field

- rapid publication on acceptance

- support for research data, including large and complex data types

- gold Open Access which fosters wider collaboration and increased citations

- maximum visibility for your research: over $100 \mathrm{M}$ website views per year

At BMC, research is always in progress.

Learn more biomedcentral.com/submissions 